\section{A) Check for updates}

Cite this: Dalton Trans., 2020, 49 6504

\title{
Synthesis and characterisation of light lanthanide bis-phospholyl borohydride complexes $\uparrow$
}

\author{
Jingjing Liu, (iD Lydia E. Nodaraki, Philip J. Cobb, (D) Marcus J. Giansiracusa, \\ Fabrizio Ortu, (D) Floriana Tuna (D) and David P. Mills (D) *
}

\begin{abstract}
Organometallic lanthanide (Ln) chemistry is dominated by complexes that contain substituted cyclopentadienyl $\left(C p^{R}\right)$ ligands. Closely related phospholyls have received less attention, and although they have proven utility in stabilising low oxidation state Ln complexes the trivalent Ln chemistry of these ligands is limited in comparison. Herein, we synthesise two families of heteroleptic $\operatorname{Ln}^{3+}$ complexes, $\left[\operatorname{Ln}(H \operatorname{tp})_{2}(\mu-\right.$ $\left.\left.\mathrm{BH}_{4}\right)\right]_{2}(\mathrm{Htp}=2,5$-di-tert-butylphospholyl; 1-Ln; $\mathrm{Ln}=\mathrm{La}, \mathrm{Ce}, \mathrm{Nd}, \mathrm{Sm})$, and [[Ln( $\left.\left.\mathrm{Htp}\right)_{2}\left(\mu-\mathrm{BH}_{4}\right)_{2} \mathrm{~K}(\mathrm{~S})\right]_{n}(\mathbf{2}-\mathbf{L n}$, $\mathrm{Ln}=\mathrm{La}, \mathrm{Ce}, \mathrm{S}=2 \mathrm{DME}, n=2 ; 3-\mathrm{Ce}, \mathrm{Ln}=\mathrm{Ce}, \mathrm{S}=\mathrm{Et}_{2} \mathrm{O}$ and THF, $\left.n=\infty\right)$ via the reactions of parent [ $\mathrm{Ln}$ $\left(\mathrm{BH}_{4}\right)_{3}(\mathrm{THF})_{3.5}$ ] with $\mathrm{K}(\mathrm{Htp})$, to investigate differences between $\mathrm{Ln}$ complexes with substituted phospholyl ligands and analogous $C \mathrm{p}^{\mathrm{R}}$ complexes. Complexes 1-3-Ln were characterised as appropriate by single crystal XRD, SQUID magnetometry, elemental analysis, multinuclear NMR, ATR-IR and UV-Vis-NIR spectroscopy. Ab initio calculations reveal that small changes in the $\mathrm{Ln}^{3+}$ coordination spheres of these complexes can have relatively large influences on crystal field splitting.
\end{abstract}

Received 3rd April 2020,

Accepted 27th April 2020

DOI: 10.1039/d0dt01241f

rsc.li/dalton 'ate' complexes, $\left[\mathrm{Ln}(\mathrm{Tmp})_{2}(\mu-\mathrm{Cl})_{2}(\mathrm{Li})(\mathrm{S})_{2}\right]\left(\mathrm{Tmp}=\mathrm{PC}_{4} \mathrm{Me}_{4} ; \mathrm{Ln}=\right.$ $\mathrm{Y}, \mathrm{S}=\mathrm{DME} ; \mathrm{Ln}=\mathrm{Lu}, \mathrm{S}=\mathrm{Et}_{2} \mathrm{O}$ ) via the salt metathesis reactions of $\mathrm{LnCl}_{3}$ with two equivalents of $\mathrm{Li}(\mathrm{Tmp}){ }^{7}$ The analogous bisborohydride 'ate' complex, $\left[\mathrm{Nd}(\mathrm{Tmp})_{2}\left(\mu-\mathrm{BH}_{4}\right)_{2}(\mathrm{~K})(\mathrm{THF})\right]$, was later obtained by the use of $\left[\mathrm{Nd}\left(\mathrm{BH}_{4}\right)_{3}(\mathrm{THF})_{3}\right]$ and $\mathrm{K}(\mathrm{Tmp})$ as starting materials. ${ }^{8}$ The employment of $\mathrm{LnI}_{3}$ precursors yielded alkali metal salt-free monomeric $\left[\operatorname{Ln}(\operatorname{Dtp})_{2}(\mathrm{I})\right](\mathrm{Ln}=\mathrm{Dy}$, Tm; Dtp $\left.=\mathrm{PC}_{4}{ }^{t} \mathrm{Bu}_{2}-2,5-\mathrm{Me}_{2}-3,4\right)$ and dimeric $\left[\mathrm{Tm}(\mathrm{Htp})_{2}(\mu-\mathrm{I})\right]_{2}$ $\left(\mathrm{Htp}=\mathrm{PC}_{4} \mathrm{H}_{2}{ }^{t} \mathrm{Bu}_{2}-2,5\right)$ or $\left[\mathrm{Dy}(\mathrm{Dsp})_{2}(\mu-\mathrm{I})\right]_{2}\left(\mathrm{Dsp}=\mathrm{PC}_{4}\left(\mathrm{SiMe}_{3}\right)_{2}{ }^{-}\right.$ $\left.2,5-\mathrm{Me}_{2}-3,4\right)$, with the degree of aggregation dependent upon the steric bulk of the phospholyl ligand. ${ }^{9,10}$ In 1995, Nief attempted to prepare a trisubstituted Sm phospholyl complex by employing the less bulky Dmp $\left(\mathrm{PC}_{4} \mathrm{H}_{2} \mathrm{Me}_{2}-2,5\right)$; dimeric [Sm $\left(\eta^{5} \text {-Dmp }\right)_{2}\left(\mu, \eta^{5}: \eta^{1}\right.$-Dmp $\left.)\right]_{2}$ was isolated. ${ }^{11}$ In 2016, Jaroschik et al. reported the first example of a monomeric tris-phospholyl $\mathrm{Ln}^{3+}$ complex, $\left[\operatorname{Tm}\left(\eta^{5}-\mathrm{Dtp}\right)_{2}\left(\eta^{1}\right.\right.$-Dtp $\left.)\right]$, which was synthesised by the oxidation of $\left[\mathrm{Tm}(\mathrm{Dtp})_{2}\right]$ with $\left[\mathrm{Pb}(\mathrm{Dtp})_{2}\right] .{ }^{12}$ One Dtp ligand in this trivalent complex exhibits an $\eta^{1}$-binding mode through the phosphorus lone pair; this is attributed to the steric demands of Dtp, and this motif contrasts with all $\eta^{5}$ coordination for bulky $\mathrm{Cp}^{\mathrm{R}}$ ligands on smaller $\mathrm{Ln}^{3+}$ ions, e.g. $\left[\operatorname{Er}\left(\mathrm{Cp}^{*}\right)_{3}\right]{ }^{13}$ Recently, our group showed that the bis-phospholyl Dy ${ }^{3+}$ complex, $\left[\mathrm{Dy}(\mathrm{Dtp})_{2}\right]\left[\mathrm{Al}\left\{\mathrm{OC}\left(\mathrm{CF}_{3}\right)_{3}\right\}_{4}\right]$, prepared by the sequential reaction of $\left[\mathrm{Dy}(\mathrm{Dtp})_{2}(\mathrm{I})\right]$ with $\mathrm{Mg}\left(\mathrm{C}_{3} \mathrm{H}_{5}\right) \mathrm{Cl}$ followed by $\left[\mathrm{NEt}_{3} \mathrm{H}\right]\left[\mathrm{Al}\left\{\mathrm{OC}\left(\mathrm{CF}_{3}\right)_{3}\right\}_{4}\right]$, was shown to be a single-molecule magnet (SMM) exhibiting magnetic hysteresis up to $48 \mathrm{~K}^{14}$

We targeted complexes of the general formula $\left[\operatorname{Ln}(\mathrm{Htp})_{3}\right]$ for the largest $\mathrm{Ln}^{3+}$ cations, in an effort to prepare structurally similar analogues of $\left[\mathrm{Ln}\left(\mathrm{Cp}^{\mathrm{tt}}\right)_{3}\right]\left(\mathrm{Ln}=\mathrm{La}, \mathrm{Ce}, \mathrm{Nd}, \mathrm{Sm} ; \mathrm{Cp}^{\mathrm{tt}}=\right.$ 
$\left.\mathrm{C}_{5} \mathrm{H}_{3}{ }^{t} \mathrm{Bu}_{2}-1,3\right),{ }^{15}$ focusing on Kramers ions and diamagnetic $\mathrm{La}^{3+}$ analogues. However, we were unable to synthesise homoleptic complexes by the salt metathesis methods outlined herein and two families of heteroleptic complexes, [Ln $\left.(\mathrm{Htp})_{2}\left(\mu-\mathrm{BH}_{4}\right)\right]_{2}(\mathbf{1}-\mathbf{L n} ; \mathrm{Ln}=\mathrm{La}, \mathrm{Ce}, \mathrm{Nd}, \mathrm{Sm})$ and $\left[\operatorname{Ln}(\mathrm{Htp})_{2}(\mu-\right.$ $\left.\left.\mathrm{BH}_{4}\right)_{2} \mathrm{~K}(\mathrm{~S})_{2}\right]_{n}$ (2-Ln; Ln = La, Ce, $\mathrm{S}=\mathrm{DME}, n=2 ; 3-\mathrm{Ce}, \mathrm{Ln}=\mathrm{Ce}$, $\mathrm{S}=\mathrm{Et}_{2} \mathrm{O}$ and THF, $n=\infty$ ), were characterised in this work by a variety of analytical techniques and ab initio calculations.

\section{Results and discussion}

\section{Synthesis}

The heteroleptic complexes 1-Ln ( $\mathrm{Ln}=\mathrm{La}, \mathrm{Ce}, \mathrm{Nd}, \mathrm{Sm})$ were prepared from the parent $\left[\mathrm{Ln}\left(\mathrm{BH}_{4}\right)_{3}(\mathrm{THF})_{3.5}\right]^{16}$ and two equivalents of $\mathrm{K}(\mathrm{Htp})^{17}$ by modification of the synthesis of $\left[\mathrm{Tm}(\mathrm{Htp})_{2}(\mu-\mathrm{I})\right]_{2}$, using $\mathrm{TmI}_{3}$ and $\mathrm{K}$ (Htp) (Scheme 1). ${ }^{9}$ Di- $n$-butyl ether was selected as the reaction solvent as its high boiling point $\left(140.8^{\circ} \mathrm{C}\right)$ allowed the reaction mixture to be heated significantly to increase the solubility of $\mathrm{K}(\mathrm{Htp})$. The crystalline yields for 1-La, 1-Ce, 1-Nd and 1-Sm were 31\%, 41\%, 15\% and 7\%, respectively, indicating that these salt metathesis reactions tend to become more sluggish for smaller $\mathrm{Ln}^{3+}$ cations. We were able to monitor the formation of diamagnetic 1-La by ${ }^{31} \mathrm{P}$ NMR spectroscopy; the reaction appeared to proceed relatively cleanly but sluggishly, with only 1-La, K(htp) and a byproduct (Htp) present in appreciable quantities, thus we postulate that the low yields of 1-Ln were due to the loss of material during recrystallization processes. The especially low isolated yields of 1-Nd and 1-Sm were attributed to the ready formation of $(\mathrm{Htp})_{2}$, which was observed in the ${ }^{31} \mathrm{P}$ NMR spectra of all reaction mixtures but appeared to form in greater quantities for the smaller Ln. The formation of (Htp $)_{2}$ in salt metathesis reactions has previously been seen in the synthesis of $[\mathrm{Ga}(\mathrm{Htp})]$ from the reaction of $\mathrm{GaBr}$ with one equivalent of $\mathrm{Li}(\mathrm{Htp}) .{ }^{18}$
The related complexes 2-Ln and 3-Ce were synthesised by analogous procedures using DME or diethyl ether, respectively, in the reactions of $\left[\mathrm{Ln}\left(\mathrm{BH}_{4}\right)_{3}(\mathrm{THF})_{3.5}\right]$ with two equivalents of $\mathrm{K}(\mathrm{Htp})$. The crystalline yields for 2-La, 2-Ce and 3-Ce were 16\%, $46 \%$ and $31 \%$, respectively; for 2 -Ln the reaction mixtures were heated but in the case of 3-Ce the reaction was performed at room temperature. Although we are unable to conclusively determine if the differences between the degree of oligomerisation in 2-Ce and 3-Ce are due to the reaction temperature as the boiling point of diethyl ether $\left(34.6^{\circ} \mathrm{C}\right)$ is far lower than that of DME $\left(85^{\circ} \mathrm{C}\right)$, it is evident that changing the solvent to diethyl ether has allowed the salt metathesis reaction to proceed at a lower temperature, which is important to note for future synthetic attempts.

In common with observations for the synthesis of 1-Ln above, the yield of 2-La was lower than 2-Ce, indicating that reaction vectors and crystallisation processes are highly sensitive to $\mathrm{Ln}^{3+}$ cation size, and that (Htp) $)_{2}$ formation is likely an issue when reaction mixtures are heated for an extended period of time. We did not adapt these methods to attempt to prepare $\mathrm{Nd}$ and $\mathrm{Sm}$ analogues for 2 - $\mathbf{L n}$. Variations of reaction stoichiometries to three equivalents of $\mathrm{K}(\mathrm{Htp})$ and changes in temperature and reaction times to those outlined above did not provide homoleptic complexes. Complexes 1-Ln, 2-Ln or 3Ce were isolated in similar crystalline yields to those stated above upon the variation of any of these parameters, though the amount of (Htp) $)_{2}$ formed in the reaction mixtures of 1-Nd and 1-Sm appeared to increase when these were heated for prolonged periods at elevated temperatures and monitored by ${ }^{31} \mathrm{P}$ NMR spectroscopy.

Elemental analysis results consistently gave low carbon values, likely due to carbide formation from incomplete combustion, but all other analytical data were consistent with their bulk purity (see below); for 3-Ce elemental analysis values are in agreement with ${ }^{1} \mathrm{H}$ NMR data where complete desolvation
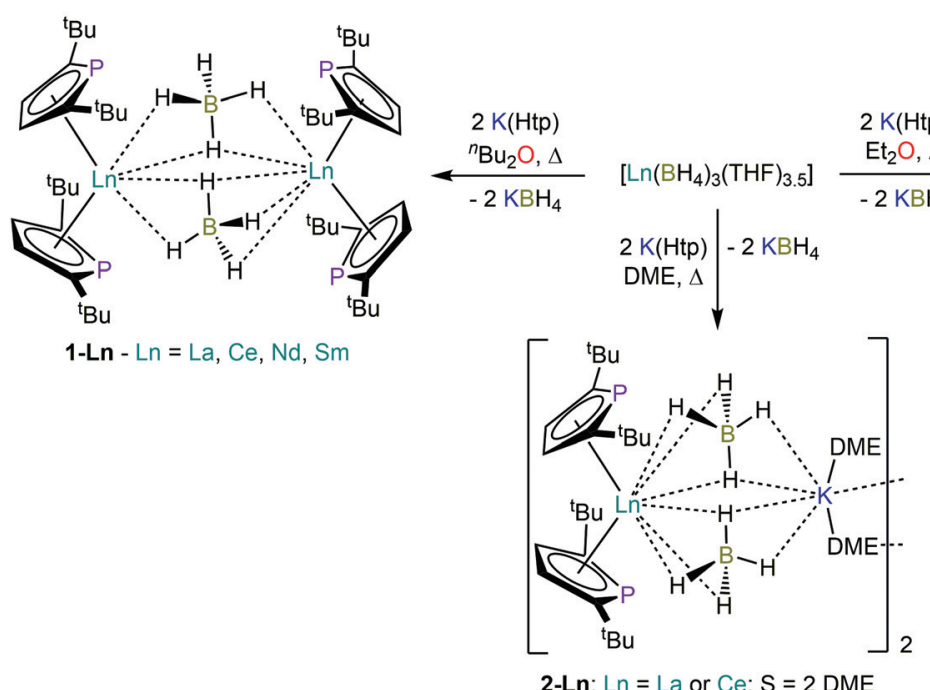

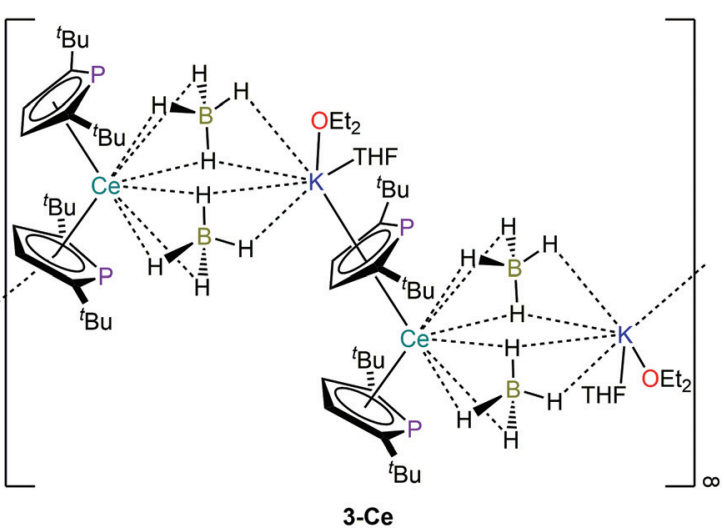

Scheme 1 Synthesis of 1-Ln, 2-Ln and 3-Ce. 
occurred when the sample was exposed to vacuum for 1 hour $\left(1 \times 10^{-2} \mathrm{mbar}\right)$. The ATR-IR spectra of most complexes clearly exhibit absorptions from 2500 to $2100 \mathrm{~cm}^{-1}$ (see ESI Fig. S47$\mathrm{S} 55 \dagger)$; these are attributed to $\mathrm{B}-\mathrm{H}$ vibrations by comparison to those reported for $\left[\mathrm{Ln}\left(\mathrm{Cp}^{\mathrm{tt}}\right)_{2}\left(\mu-\mathrm{BH}_{4}\right)\right]_{2}(\mathrm{Ln}=\mathrm{La}, \mathrm{Ce}, \mathrm{Sm}) \cdot{ }^{16 b, 19}$ As expected the ATR-IR spectra of 2-La and 2-Ce are nearly superimposable, but 1-Ln fall into two distinct pairs, with analogous spectra for 1-La and 1-Sm, and for 1-Ce and 1-Nd; this observation is curious given that the single crystal XRD data indicate that 1-Ln are all structurally analogous in the solid state (see below).

\section{NMR spectroscopy}

${ }^{1} \mathrm{H}$ NMR spectra were recorded from -350 to $+350 \mathrm{ppm}$ for 1Ln, 2-Ln and 3-Ce, though paramagnetic shifts were relatively small for Ce, Nd and Sm analogues (Table 1). Two signals were observed in all spectra in a ratio of $36: 4$; these correspond to the ${ }^{t} \mathrm{Bu}$ groups and the Htp ring protons, respectively. Due to restricted rotation of the Htp rings in 2-La, we observed two ${ }^{t} \mathrm{Bu}$ group resonances at $298 \mathrm{~K}$; VT ${ }^{1} \mathrm{H}$ NMR spectra in $\mathrm{C}_{7} \mathrm{D}_{8}$ from 218-318 $\mathrm{K}$ showed that these two signals coalesced at $318 \mathrm{~K}$, and exhibited greater separation at lower temperatures with an approximate rotational energy barrier of $31(7) \mathrm{kJ} \mathrm{mol}^{-1}$ (see ESI $\dagger$ ). The $\mathrm{BH}_{4}{ }^{-}$anions were not seen in the ${ }^{1} \mathrm{H}$ NMR spectra of 1-Ln, 2-Ln and 3-Ce, even for diamagnetic 1-La and 2-La, but were observed by ${ }^{11} \mathrm{~B}\left\{{ }^{1} \mathrm{H}\right\}$ NMR spectroscopy $\left[\delta_{\mathrm{B}}\right.$ : -20.89 (1-La), -3.90 (1-Ce), -71.18 (1-Sm), -22.70 and -20.89 (2-La), 13.35 (2-Ce)]. For 1-La B-H coupling $\left({ }^{1} J_{\mathrm{BH}}=84.1 \mathrm{~Hz}\right)$ was observed in the ${ }^{11} \mathrm{~B}$ NMR spectrum; a similar coupling constant was previously seen for $\left[\mathrm{La}\left(\mathrm{Cp}^{\mathrm{tt}}\right)_{2}\left(\mu-\mathrm{BH}_{4}\right)\right]_{2}\left({ }^{1} J_{\mathrm{BH}}=81\right.$ $\mathrm{Hz}){ }^{16 b}$

The paramagnetism of 1-Ce, 1-Nd, 1-Sm, 2-Ce and 3-Ce precluded assignment of their ${ }^{13} \mathrm{C}\left\{{ }^{1} \mathrm{H}\right\}$ NMR spectra, however, for diamagnetic 1-La and 2-La these could be interpreted: for 1-La the expected two ${ }^{t} \mathrm{Bu}$ group resonances were observed at 34.50 and $37.02 \mathrm{ppm}$ and the two Htp ring carbon environments were located at 125.01 and $178.08 \mathrm{ppm}$. The signals for carbon atoms on the Htp ring and ${ }^{t} \mathrm{Bu}$ groups are doublets from coupling with ${ }^{31} \mathrm{P}\left({ }^{1} J_{\mathrm{PC}}=59.7 \mathrm{~Hz} ;{ }^{2} J_{\mathrm{PC}}=15.7 \mathrm{~Hz} ;{ }^{3} J_{\mathrm{PC}}=6.9 \mathrm{~Hz}\right)$; similar coupling constants were previously seen for $\left[\mathrm{Pb}(\mathrm{Dtp})_{2}\right]$ $\left({ }^{1} J_{\mathrm{PC}}=45.8 \mathrm{~Hz} ;{ }^{2} J_{\mathrm{PC}}=16.2\right.$ and $\left.3.4 \mathrm{~Hz}\right)$ and $\left[\mathrm{Pb}(\mathrm{Dsp})_{2}\right]\left({ }^{1} J_{\mathrm{PC}}=\right.$ $\left.66.0 \mathrm{~Hz} ;{ }^{2} \mathrm{JC}_{\mathrm{PC}}=3.0 \mathrm{~Hz} ;{ }^{3} \mathrm{~J}_{\mathrm{PC}}=6.0 \mathrm{~Hz}\right) .{ }^{12}$ The Htp ring was only observed by ${ }^{31} \mathrm{P}\left\{{ }^{1} \mathrm{H}\right\}$ NMR spectroscopy for diamagnetic 1-La

Table $1{ }^{1} \mathrm{H}$ NMR spectra assignments of $\mathrm{Htp}$ rings of 1-Ln, 2-Ln and 3$\mathrm{Ce}$ in $\mathrm{C}_{6} \mathrm{D}_{6}$

\begin{tabular}{lll}
\hline Complex & $\delta{ }^{1} \mathrm{H} / \mathrm{ppm}\left\{\mathrm{PC}_{4} \mathrm{H}_{2} \mathrm{C}\left(\mathrm{CH}_{3}\right)_{3}\right\}$ & $\delta{ }^{1} \mathrm{H} / \mathrm{ppm}\left\{\mathrm{PC}_{4} \mathrm{H}_{2} \mathrm{C}\left(\mathrm{CH}_{3}\right)_{3}\right\}$ \\
\hline 1-La & $1.52,72 \mathrm{H}$ & $7.35,8 \mathrm{H}$ \\
1-Ce & $-3.70,72 \mathrm{H}$ & $-2.64,4 \mathrm{H} ;-4.63,4 \mathrm{H}$ \\
1-Nd & $-5.09,72 \mathrm{H}$ & $-13.86,8 \mathrm{H}$ \\
1-Sm & $-0.54,72 \mathrm{H}$ & $16.40,8 \mathrm{H}$ \\
2-La & $1.50,36 \mathrm{H} ; 1.75,36 \mathrm{H}$ & $7.2-7.4,8 \mathrm{H}$ \\
2-Ce & $-1.84,24 \mathrm{H} ;-3.68,48 \mathrm{H}$ & $11.35,8 \mathrm{H}$ \\
3-Ce & $-3.45,36 \mathrm{H}$ & $1.44,4 \mathrm{H}$
\end{tabular}

$\left(\delta_{\mathrm{P}}: 105.65 \mathrm{ppm}\right)$ and 2-La $\left(\delta_{\mathrm{P}}: 96.49 \mathrm{ppm}\right)$, however, for paramagnetic 1-Ln, 2-Ce and 3-Ce only diamagnetic impurities and $(\mathrm{Htp})_{2}$ were observed at ca. $-62 \mathrm{ppm}$ and $-24 \mathrm{ppm}$, respectively.

\section{Crystallography}

The solid-state structures of 1-Ln, 2-Ln and 3-Ce were determined by single crystal XRD (1-Ce, 2-Ce and 3-Ce are depicted in Fig. 1, selected bond distances and angles are compiled in Table 2; see ESI† for additional crystallographic data). Due to the poor data quality for 1-Nd metrical parameters are not included, however the data is of sufficient quality to provide connectivity. All $\mathrm{Ln}^{3+}$ cations in 1-Ln, 2-Ln and 3-Ce are capped with two $\eta^{5}$-Htp ligands and have two equatorial $\mathrm{BH}_{4}{ }^{-}$ anions. For the dinuclear 1-Ln series the $\mathrm{BH}_{4}{ }^{-}$anions bridge
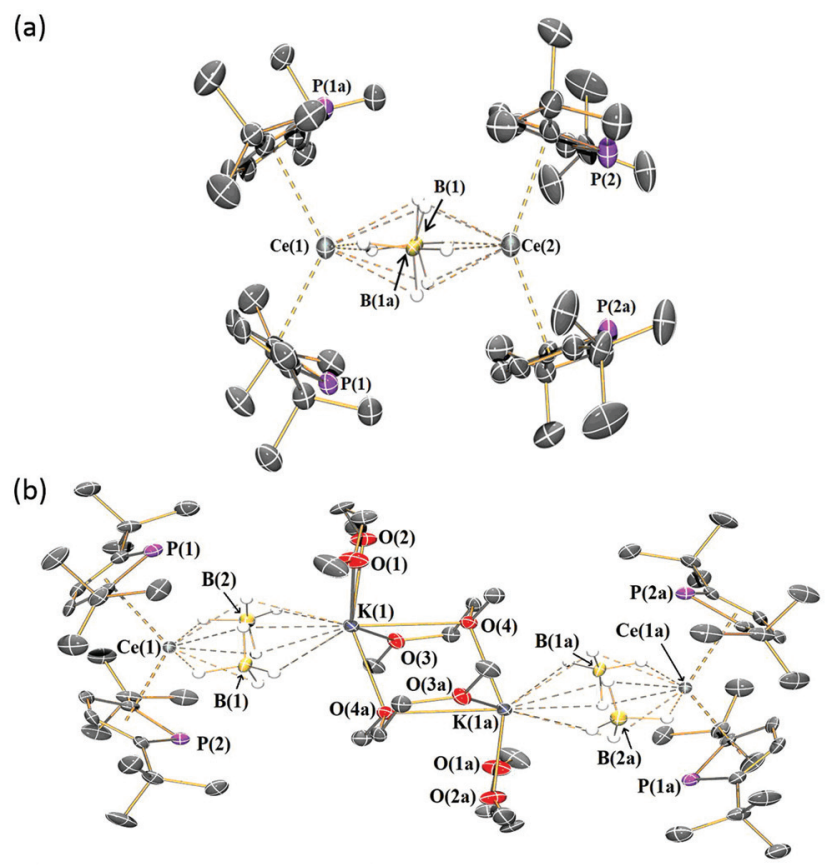

(c)

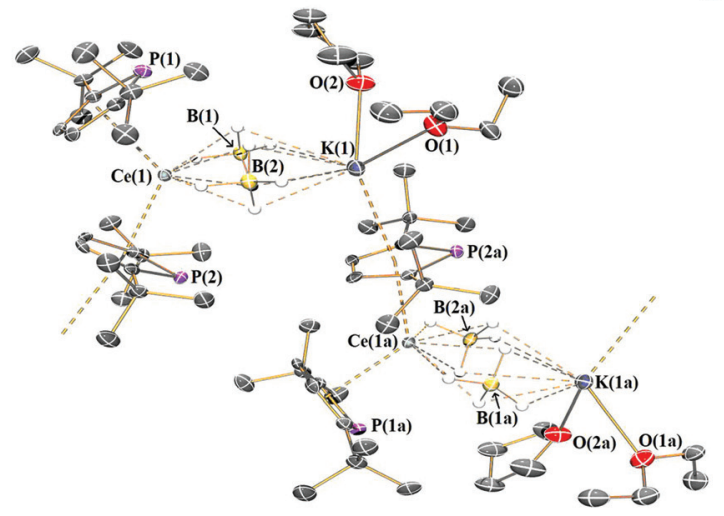

Fig. 1 Molecular structure of (a) 1-Ce, (b) 2-Ce and (c) 3-Ce, with selected atom labelling. Displacement ellipsoids set at 30\% probability level and hydrogen atoms and lattice solvent apart from those on $\mathrm{BH}_{4}{ }^{-}$ anions are omitted for clarity. 
Table 2 Selected bond distances and angles of 1-Ln, 2-Ln and 3-Ce. Data for 1-Nd excluded due to their low quality

\begin{tabular}{|c|c|c|c|}
\hline Complex & Ln $\cdots$ Htp cent $/ \AA$ & $\begin{array}{l}\text { Htp }_{\text {cent }} \cdots \operatorname{Ln} \cdots \\
\text { Htp }_{\text {cent }} /{ }^{\circ}\end{array}$ & $\mathrm{Ln} \cdots \mathrm{B} / \AA$ \\
\hline 1-La (La(1)) & $2.634(7)$ & $123.7(2)$ & $2.855(13)$ \\
\hline$(\mathrm{La}(2))$ & $2.664(6)$ & $141.0(2)$ & $2.914(13)$ \\
\hline 1-Ce (Ce(1)) & $2.605(6)$ & $123.5(2)$ & $2.904(12)$ \\
\hline$(\mathrm{Ce}(2))$ & $2.626(6)$ & $140.1(2)$ & $3.009(12)$ \\
\hline 1-Sm $(\operatorname{Sm}(1))$ & $2.544(6)$ & $124.7(2)$ & $2.806(16)$ \\
\hline$(\operatorname{Sm}(2))$ & $2.578(7)$ & $141.8(2)$ & $2.939(16)$ \\
\hline 2-La & $2.6721(11), 2.6672(11)$ & $121.23(3)$ & $2.723(4), 2.724(3)$ \\
\hline 2-Ce & $2.6288(18), 2.6337(18)$ & $121.63(6)$ & $2.698(5), 2.699(6)$ \\
\hline 3-Ce & $2.632(2), 2.683(2)$ & $121.40(7)$ & $2.695(5), 2.705(7)$ \\
\hline
\end{tabular}

two $\mathrm{Ln}^{3+}$ cations, whereas for 2-Ln and 3-Ce these bridge one $\mathrm{Ln}^{3+}$ and one $\mathrm{K}^{+}$cation.

In the case of $2-\mathbf{L n}$ the $\mathrm{K}^{+}$cations are bound by two DME molecules, one of which bridges to the $\mathrm{K}^{+}$cation of a second $\left[\mathrm{Ln}(\mathrm{Htp})_{2}\left(\mu-\mathrm{BH}_{4}\right)_{2} \mathrm{~K}(\mathrm{DME})(\mu-\mathrm{DME})\right]$ unit. In contrast, the $\mathrm{K}^{+}$ cations of 3-Ce are bound by one THF, one diethyl ether, and an $\eta^{5}$-Htp that bridges to the $\mathrm{Ce}^{3+}$ centre of the next [Ce $\left.(\mathrm{Htp})_{2}\left(\mu-\mathrm{BH}_{4}\right)_{2} \mathrm{~K}(\mathrm{THF})\left(\mathrm{Et}_{2} \mathrm{O}\right)\right]$ unit, forming a coordination polymer. In all cases, we are not fully confident in assigning precise binding modes of $\mathrm{BH}_{4}{ }^{-}$anions from the combination of ATR-IR spectra and XRD data.

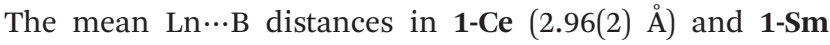
$(2.87(2) \AA)$ are comparable to those in $\left[\operatorname{Ln}\left(\mathrm{Cp}^{\mathrm{tt}}\right)_{2}\left(\mu-\mathrm{BH}_{4}\right)\right]_{2}(\mathrm{Ln}=$

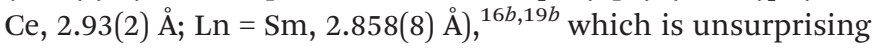
given the similarity in size of $\mathrm{Htp}$ and $\mathrm{Cp}^{\mathrm{tt}}$. The mean

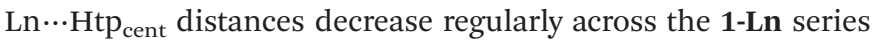

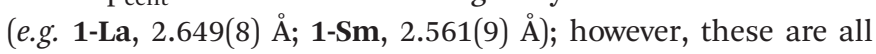
larger than the corresponding $\mathrm{Ln} \cdot \mathrm{CP}_{\mathrm{C} e n t}$ distances in [Ln $\left.\left(\mathrm{Cp}^{\mathrm{tt}}\right)_{2}\left(\mu-\mathrm{BH}_{4}\right)\right]_{2}(\mathrm{Ln}=\mathrm{Ce}, 2.535 \AA$ 践 $=\mathrm{Sm}, 2.46 \AA) .{ }^{19}$

All the 1-Ln series exhibit two sets of Htp cent $\cdots$ Ln $\cdots$ Htp cent angles $\left(\mathrm{Ln}=\mathrm{La}, 123.5(2)^{\circ}\right.$ and 141.2(2) ${ }^{\circ} ; \mathrm{Ln}=\mathrm{Ce}, 123.4(2)^{\circ}$ and $140.2(2)^{\circ} ; \mathrm{Ln}=\mathrm{Sm}, 124.5(3)^{\circ}$ and $\left.141.8(3)^{\circ}\right)$; these are all closer to linearity than the mean $\mathrm{Cp}_{\text {cent }}^{\mathrm{tt}} \cdots \mathrm{Ln} \cdots \mathrm{Cp}_{\text {cent }}^{\mathrm{tt}}$ angles in $\left[\mathrm{Ln}\left(\mathrm{Cp}^{\mathrm{tt}}\right)_{2}\left(\mu-\mathrm{BH}_{4}\right)\right]_{2}\left(\mathrm{Ln}=\mathrm{Ce}, 119.4^{\circ} ; \mathrm{Ln}=\mathrm{Sm}, 115.2^{\circ}\right) .{ }^{19}$ The mean Ln $\cdots$ Htp $_{\text {cent }}$ distances in 2-La (2.670(2) $\AA$ ) are slightly longer than those in 2-Ce (2.631(3) ̊) but are statistically equivalent to those in 3-Ce (2.658(3) Å).

\section{Electronic spectroscopy}

The electronic spectra of 1-Ln, 2-Ln and 3-Ce were obtained at room temperature as ca. $0.5 \mathrm{mM}$ solutions in toluene (UV-VisNIR spectra of 1-Ln compiled in Fig. 2; other spectra are shown in the ESI†). All complexes exhibited intense ligandmetal charge transfer bands, which tailed into the visible region from the UV to varying extents. Due to their Laporte-forbidden nature, $\mathrm{f}-\mathrm{f}$ transitions are relatively weak; ${ }^{20}$ pale green 1-Nd exhibits an absorption at $\tilde{\nu}_{\max }=16750 \mathrm{~cm}^{-1}(\varepsilon=$ $390 \mathrm{~mol}^{-1} \mathrm{dm}^{3} \mathrm{~cm}^{-1}$ ), owing to the ${ }^{4} \mathrm{I}_{9 / 2} \rightarrow{ }^{4} \mathrm{G}_{5 / 2}$ transitions. ${ }^{20}$ No $\mathrm{f}-\mathrm{f}$ transitions could be observed for the other complexes. Complex 1-Ce showed two very broad but distinguishable absorptions at ca. $21000 \mathrm{~cm}^{-1}$ and $23000 \mathrm{~cm}^{-1}$ with similar

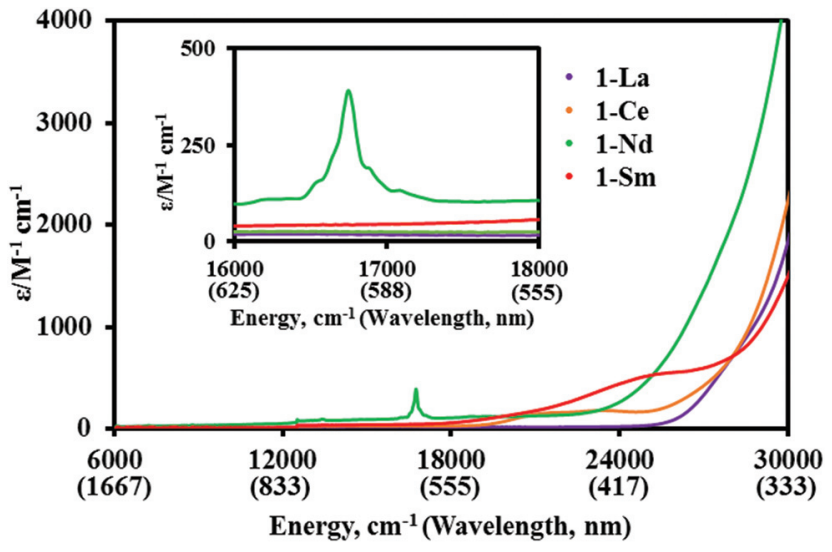

Fig. 2 UV-vis-NIR spectra of 1-Ln (ca. $0.5 \mathrm{mM}$ in toluene) from 6000 to $21000 \mathrm{~cm}^{-1}$ at room temperature.

extinction coefficients $\left(\varepsilon \approx 200 \mathrm{~mol}^{-1} \mathrm{dm}^{3} \mathrm{~cm}^{-1}\right)$, whereas 2-Ce and 3-Ce showed similar broad absorptions at $21300 \mathrm{~cm}^{-1}(\varepsilon=$ $200 \mathrm{~mol}^{-1} \mathrm{dm}^{3} \mathrm{~cm}^{-1}$ and $250 \mathrm{~mol}^{-1} \mathrm{dm}^{3} \mathrm{~cm}^{-1}$, respectively). These absorptions are assigned to $[\mathrm{Xe}] 4 \mathrm{f}^{1} \rightarrow[\mathrm{Xe}] 4 \mathrm{f}^{0} 5 \mathrm{~d}^{1}$ transitions, which are formally allowed by electric dipole selection rules, though the extinction coefficients are relatively small and are typically $\mathrm{ca}$. $600-1200 \mathrm{~mol}^{-1} \mathrm{dm}^{3} \mathrm{~cm}^{-1}$ for $\mathrm{Ce}^{3+} \mathrm{com}-$ plexes; this is attributed to a combination of the low local symmetry and dipole-dipole effects. ${ }^{20}$

\section{Magnetism}

We were unable to collect reliable EPR spectroscopic data for paramagnetic 1-Ln, 2-Ln and 3-Ce as powders or as frozen toluene solutions. Multiple measurements were attempted at both $\mathrm{X}$ and K-band frequencies to probe the electronic structure and the presence of exchange interactions. The sample stability and weak signal, including issues with grinding polycrystalline samples, the presence of inequivalent $\mathrm{Ln}^{3+}$ sites and multiple hyperfine splittings (by ${ }^{31} \mathrm{P},{ }^{10} \mathrm{~B}$ and ${ }^{11} \mathrm{~B}$ nuclei), proved problematic for obtaining reliable and reproducible spectra and as such discussion of these data is omitted. However, variable temperature DC magnetic measurements were recorded for all paramagnetic complexes as solids suspended in eicosane by SQUID magnetometry with $0.1 \mathrm{~T}$ applied magnetic field, or in solution at $298 \mathrm{~K}$ by the Evans $\operatorname{method}^{21}$ (see ESI $\dagger$ for full details). Relatively small discrepancies between solid and solution $\chi_{\mathrm{M}} T$ values for all samples are attributed to weighing errors and the estimation of diamagnetic corrections. The magnetic susceptibility-temperature product $\left(\chi_{\mathrm{M}} T\right)$ for solid 1-Ce at $300 \mathrm{~K}$ was $1.32 \mathrm{~cm}^{3} \mathrm{~mol}^{-1} \mathrm{~K}$, which is similar to the solution value of $1.47 \mathrm{~cm}^{3} \mathrm{~mol}^{-1} \mathrm{~K}$ but lower than the expected value for a dinuclear $\mathrm{Ce}^{3+}$ complex of $1.60 \mathrm{~cm}^{3} \mathrm{~mol}^{-1} \mathrm{~K}\left(\mathrm{~S}=1 / 2, \mathrm{~L}=3,{ }^{2} \mathrm{~F}_{5 / 2}\right) .{ }^{1}$ For solid 1-Nd the $300 \mathrm{~K} \chi_{\mathrm{M}} T$ value of $2.68 \mathrm{~cm}^{3} \mathrm{~mol}^{-1} \mathrm{~K}$ is higher than the solution value of $2.02 \mathrm{~cm}^{3} \mathrm{~mol}^{-1} \mathrm{~K}$ but is lower than the calculated value of $3.26 \mathrm{~cm}^{3} \mathrm{~mol}^{-1} \mathrm{~K}$ for two non-interacting $\mathrm{Nd}^{3+}$ ions ( $\mathrm{S}$ $\left.=3 / 2, \mathrm{~L}=6,{ }^{4} \mathrm{I}_{9 / 2}\right)$. In contrast, the $\chi_{\mathrm{M}} T$ product for $\mathbf{1}-\mathrm{Sm}$ at 
$300 \mathrm{~K}\left(0.61 \mathrm{~cm}^{3} \mathrm{~mol}^{-1} \mathrm{~K}\right)$ is consistent with the solution value $\left(0.71 \mathrm{~cm}^{3} \mathrm{~mol}^{-1} \mathrm{~K}\right)$, but both are higher than the expected value of a dinuclear $\mathrm{Sm}^{3+}$ complex $\left(0.18 \mathrm{~cm}^{3} \mathrm{~mol}^{-1} \mathrm{~K} ; \mathrm{S}=5 / 2\right.$, $\left.\mathrm{L}=5,{ }^{6} \mathrm{H}_{5 / 2}\right)$. Experimentally obtained $\chi_{\mathrm{M}} T$ for $\mathrm{Sm}^{3+}$ complexes are consistently higher than free-ion values due to the mixing of low lying J multiplets. ${ }^{1}$

The $\chi_{\mathrm{M}} T$ values at $300 \mathrm{~K}$ for solid 2-Ce $\left(1.16 \mathrm{~cm}^{3} \mathrm{~mol}^{-1} \mathrm{~K}\right)$ and 3-Ce $\left(0.63 \mathrm{~cm}^{3} \mathrm{~mol}^{-1} \mathrm{~K}\right)$ are similar to solution moments (1.55 and $0.68 \mathrm{~cm}^{3} \mathrm{~mol}^{-1} \mathrm{~K}$, respectively). A dinuclear formulation was used to calculate the moment of 2-Ce and a single $\mathrm{Ce}^{3+}$ centre was used in the calculation for polymeric 3-Ce; as a result the moment of 2-Ce is similar to 1-Ce, and that of 3-Ce is approximately half that of 1-Ce. Again these values are lower than the predicted free-ion $\chi_{\mathrm{M}} T$ values $\left(0.80 \mathrm{~cm}^{3} \mathrm{~mol}^{-1} \mathrm{~K}\right.$ for a single $\mathrm{Ce}^{3+}$ ion; $\mathrm{S}=1 / 2, \mathrm{~L}=3,{ }^{2} \mathrm{~F}_{5 / 2}$ ), consistent with the results obtained for 1-Ln. The low temperature magnetisation measurements of 1-Ce, 1-Nd and 1-Sm measured between 0-7 $\mathrm{T}$ at temperatures of $2 \mathrm{~K}$ and $4 \mathrm{~K}$ did not reach magnetic saturation, which can be ascribed to the large magnetic anisotropy of the system and/or to the presence of low-lying excited states. $^{22}$ In contrast, the isothermal magnetisation curves for 2-Ce and 3-Ce at $2 \mathrm{~K}$ exhibit near-saturation at $7 \mathrm{~T}$.

\section{CASSCF-SO calculations}

In order to probe the variation in the crystal field $(\mathrm{CF})$ environments of 1-Ln, 2-Ln and 3-Ce, complete active-space self-consistent field spin-orbit (CASSCF-SO) calculations were performed with Molcas $8.0^{23}$ using the X-ray crystal coordinates. For polymeric 3-Ce, a molecular fragment containing two $\mathrm{K}^{+}$ions and a single $\mathrm{Ce}^{3+}$ ion was used, completing the ligand coordination sphere around each $\mathrm{K}^{+}$; see ESI $\dagger$ for full details. The CF splitting of the ground $J$ Russell-Saunders terms are presented in Tables S5-S12. $\dagger$ The theoretically predicted magnetic properties were compared to the experimentally determined susceptibility and magnetisation curves. For 1-Ce, 1-Sm and 3-Ce, ab initio calculations are in good agreement with experimental data, whilst for all other paramagnetic complexes the experimentally obtained values are all lower than those calculated, as is also seen by Curie law comparison of the room temperature $\chi_{\mathrm{M}} T$. The strong CASSCF agreement for 1-Sm, which was not predicted by the Curie Law, arises from temperature independent paramagnetism owing to large CF splitting and a weakly magnetic ground doublet state. ${ }^{1}$

For the 1-Ln series, the two inequivalent $\mathrm{Ln}^{3+}$ ion sites result in unique CF splitting of the ground free ion $J$ multiplets (Tables S5-S10†). These sites can be distinguished by the orientation of the $\mathrm{P}$ atoms in the Htp rings with respect to the bridging $\mathrm{BH}_{4}^{-}$moieties: $\operatorname{Ln}(1)$ refers to the smaller $\mathrm{Htp}_{\text {cent }} \cdots \mathrm{Ln} \cdots \mathrm{Htp}_{\text {cent }}$ angle where the $\mathrm{P}$ atoms are positioned relatively close to $\mathrm{BH}_{4}{ }^{-}$, whilst $\mathrm{Ln}(2)$ refers to the CF environment with the larger Htp $\mathrm{H}_{\text {cent }} \cdots \mathrm{Ln} \cdot \mathrm{HHtp}_{\text {cent }}$ angle where the P atoms are far away from $\mathrm{BH}_{4}{ }^{-}$. Consistently, $\mathrm{Ln}(2)$ has a larger overall CF splitting of the $m_{J}$ sublevels, which follows the trend with linearity of the $\mathrm{Htp}_{\text {cent }} \cdots \mathrm{Ln} \cdots \mathrm{Htp}_{\text {cent }}$ angle. Complex 1-Ce reveals the most dramatic contrast between the two sites, with
Ce(2) having ca. 50\% larger CF splitting $\left(892 \mathrm{~cm}^{-1}\right)$ than $\mathrm{Ce}(1)$ $\left(626 \mathrm{~cm}^{-1}\right)$; this contrast is also observed for $\mathrm{Nd}$ and $\mathrm{Sm}$ but to a much smaller extent ( $<20 \%$ difference in CF splitting). As there is almost no variation in the Ln $\cdots$ Htp $_{\text {cent }}$ distances of the two sites, the CF splitting behaviour is likely a result of the coordination angle of the Htp ligands and influenced by the skewed electron density resulting from the position of the $\mathrm{P}$ atom within the Htp ring. There is ca. $0.1 \AA$ difference between the $\mathrm{Ln} \cdots \mathrm{B}$ distances of each site from the bridging $\mathrm{BH}_{4}{ }^{-}$moieties across all variants. Here, the longer Ln $\cdots \mathrm{B}$ interaction is always $\operatorname{Ln}(2)$, with the larger $\mathrm{Htp}_{\text {cent }} \cdots \operatorname{Ln} \cdots$ Htp ${ }_{\text {cent }}$ angle.

For the Ce Htp complexes (Tables S5, S6, S11 and S12 $\dagger$ ), the coordination environment of $\mathrm{Ce}(1)$ from 1-Ce shows a similar bonding motif of the Htp ligands with 2-Ce and 3-Ce (Table 2). Despite the similar Ce...Htp bond lengths and angles, the $\mathrm{BH}_{4}{ }^{-}$anions are closer to the $\mathrm{Ce}^{3+}$ ions in 2-Ce and 3-Ce com-

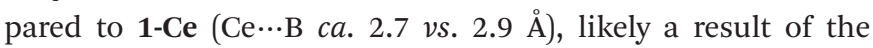
smaller neighbouring $\left\{\mathrm{K}(\mathrm{S})_{2}\right\}^{+}$coordination spheres instead of the sterically demanding $\left\{\mathrm{Ce}(\mathrm{Htp})_{2}\right\}^{+}$moiety. This closer interaction results in a significantly smaller CF splitting in 2-Ce and 3-Ce (285 and $320 \mathrm{~cm}^{-1}$, respectively) and provides a direct representation of the influence of the weak interactions from the $\mathrm{BH}_{4}{ }^{-}$anions. It has previously been shown that control and minimisation of equatorial anion interactions in isolated $\left[\mathrm{Dy}\left(\mathrm{Cp}^{\mathrm{R}}\right)_{2}\right]^{+}$and $\left[\mathrm{Dy}(\mathrm{Dtp})_{2}\right]^{+}$cations is of crucial importance in high-performance SMM design. ${ }^{14,24}$ Our results highlight that small variations to the equatorial ligand field in almost identical $\left\{\operatorname{Ln}(\mathrm{Htp})_{2}\right\}^{+}$moieties can have a relatively large influence on the CF splitting of $\mathrm{Ln}^{3+}$ ions, and hence a potentially significant impact on the resultant magnetic properties for late $\mathrm{Ln}^{3+}$ analogues.

As a further point of comparison, CASSCF-SO calculations were performed on the literature complex $\left[\mathrm{Ce}\left(\mathrm{Cp}^{\mathrm{tt}}\right)_{2}\left(\mu-\mathrm{BH}_{4}\right)\right]_{2}$ (4-Ce) (Tables S13 and S14 $\dagger$ ). ${ }^{25}$ This system has two unique $\mathrm{Ce}^{3+}$ coordination environments, albeit with minimal differences in metrical parameters $\left(\mathrm{Cp}_{\text {cent }}^{\mathrm{tt}} \cdots \mathrm{Ln} \cdots \mathrm{C} \mathrm{p}_{\text {cent }}^{\mathrm{tt}}\right.$ angles of 119.2 and $119.6^{\circ}$, Ce $\cdots \mathrm{Cp}_{\text {cent }}^{\mathrm{tt}}$ distances of 2.53 and $2.54 \AA$, and Ce...B distances of $2.93(2) \AA$ ). Interestingly, the coordination environment of 4-Ce is similar to $\mathrm{Ce}(1)$ from 1-Ce (with slightly shorter $\mathrm{Ce} \cdot \mathrm{Cp}_{\text {cent }}^{\mathrm{tt}}$ distances due to the less sterically demanding $\mathrm{Cp}^{\text {tt }}$ ligand), though the $\mathrm{C}_{1}$-positions on both $\left\{\mathrm{Ln}\left(\mathrm{Cp}^{\mathrm{tt}}\right)_{2}\right\}^{+}$moieties in 4-Ce are always the closest ring carbon atoms to the $\mathrm{BH}_{4}{ }^{-}$units, which contrasts the alternating coordination observed in 1-Ce. This is likely a result of minor steric differences between the $\mathrm{Cp}^{\text {tt }}$ and Htp ligands. The CF splitting of the ground $J$ multiplet is similar in these two systems $\left(626 \mathrm{~cm}^{-1}\right.$ for $\mathrm{Ce}(1)$ in 1-Ce vs. 642 and $677 \mathrm{~cm}^{-1}$ for 4-Ce; Tables S5, S13 and S14 $\dagger$ ), therefore, the inclusion of the $\mathrm{P}$ heteroatom appears to have minimal effect on the overall CF splitting and ground state stabilisation. However, since the Ce $\cdots$ Htp bond lengths are longer, Htp must have a more significant influence on the $\mathrm{CF}$ than $\mathrm{Cp}^{\text {tt }}$ in order to arrive at the same magnitude of CF splitting. Whether this is due to $\mathrm{P}$ substitution causing an overall increase in ring electron density, or a result of localisation of the electron charge, is unclear. 


\section{Conclusions}

We have synthesised two families of heteroleptic light $\mathrm{Ln}^{3+}$ complexes with the substituted phospholyl ligand Htp, focusing on Kramers ions and diamagnetic $\mathrm{La}^{3+}$ analogues. In the solid state, the two $\left\{\operatorname{Ln}(\mathrm{Htp})_{2}\right\}^{+}$fragments of $\left[\operatorname{Ln}(\mathrm{Htp})_{2}\left(\mu-\mathrm{BH}_{4}\right)\right]_{2}$ ( $\mathrm{Ln}=\mathrm{La}, \mathrm{Ce}, \mathrm{Nd}, \mathrm{Sm}$ ) exhibit significantly different geometries. This is in contrast to the analogous $\mathrm{Cp}^{\text {tt }}$ complexes [Ln $\left.\left(\mathrm{Cp}^{\mathrm{tt}}\right)_{2}\left(\mu-\mathrm{BH}_{4}\right)\right]_{2}$, showing that sterically similar phospholyl and $\mathrm{Cp}^{\mathrm{R}} \mathrm{Ln}^{3+}$ complexes can show divergent structural behaviour. For the second family of complexes $\left[\mathrm{Ln}(\mathrm{Htp})_{2}\left(\mu-\mathrm{BH}_{4}\right)_{2} \mathrm{~K}(\mathrm{~S})_{2}\right]_{n}$, a VT NMR spectroscopic study of the $\mathrm{La}^{3+}$ analogue revealed restricted rotation of the Htp rings in solution. Ab initio calculations of the $\left[\mathrm{Ln}(\mathrm{Htp})_{2}\left(\mu-\mathrm{BH}_{4}\right)\right]_{2}$ series showed that there could be dramatic differences in the extent of CF splitting of the two unique $\mathrm{Ln}^{3+}$ sites due to the strong influence of the relative orientation of ring $\mathrm{P}$ atoms with $\mathrm{Ln}^{3+}$ centres, but we also observed significant $\mathrm{CF}$ effects by variation of equatorial Ln $\cdots$ B distances with constant Htp $\cdots$ Ln $\cdots$ Htp axial fields. Comparisons of the CF splittings in $\left[\mathrm{Ce}(\mathrm{Htp})_{2}\left(\mu-\mathrm{BH}_{4}\right)\right]_{2}$ with $\left[\mathrm{Ce}\left(\mathrm{Cp}^{\mathrm{tt}}\right)_{2}\left(\mu-\mathrm{BH}_{4}\right)\right]_{2}$ indicated that Htp has a relatively large influence on the $\mathrm{CF}$ compared to $\mathrm{Cp}^{\text {tt }}$, which we attribute to either charge localisation or increased ring electron density in Htp due to P substitution. We envisage that such subtle differences in phospholyl and $\mathrm{Cp}^{\mathrm{R}} \mathrm{Ln}^{3+}$ chemistry could be of importance in the construction of geometrically precise f-element complexes, and more specifically for CF engineering in Ln SMM design.

\section{Experimental}

\section{Materials and methods}

All manipulations were carried out using standard Schlenk line and glove box techniques under dry argon. Solvents were passed through columns containing alumina or were dried by refluxing over $\mathrm{K}$, and were stored over $\mathrm{K}$ mirrors or $4 \AA$ molecular sieves (THF) and degassed before use. For NMR spectroscopy, $\mathrm{C}_{6} \mathrm{D}_{6}$ and $\mathrm{C}_{7} \mathrm{D}_{8}$ were dried by refluxing over $\mathrm{K}$. NMR solvents were degassed by three freeze-pump-thaw cycles, and vacuum-transferred before use. $\left[\mathrm{Ln}\left(\mathrm{BH}_{4}\right)_{3}(\mathrm{THF})_{4}\right](\mathrm{Ln}=\mathrm{La}$, Ce, $\mathrm{Nd}, \mathrm{Sm})^{16}$ and $\mathrm{K}(\mathrm{Htp})^{17}$ were prepared according to literature methods and $\mathrm{KBH}_{4}$ was used as received. ${ }^{1} \mathrm{H}$ (400 and $500 \mathrm{MHz}),{ }^{13} \mathrm{C}\left\{{ }^{1} \mathrm{H}\right\}$ (100 and $\left.125 \mathrm{MHz}\right),{ }^{31} \mathrm{P}\left\{{ }^{1} \mathrm{H}\right\}$ (162 and $202 \mathrm{MHz}$ ), and ${ }^{11} \mathrm{~B}\left\{{ }^{1} \mathrm{H}\right\}$ (128 and $160 \mathrm{MHz}$ ) NMR spectra were obtained on Avance III 400 or $500 \mathrm{MHz}$ spectrometers at 298 K. EPR spectroscopy measurements were performed at $\mathrm{X}$-band using a Bruker super-high-Q resonator, and at K-band with a standard cavity, both attached to a Bruker EMX bridge, on powder samples in quartz EPR tubes that were flame-sealed under vacuum. UV-vis-NIR spectroscopy was performed on samples in Youngs tap-appended $10 \mathrm{~mm}$ path length quartz cuvettes on an Agilent Technologies Cary Series UV-vis-NIR spectrophotometer at 175-3300 $\mathrm{nm}$. ATR-Fourier transform infrared (ATR-IR) spectra were recorded as microcrystalline powders using a Bruker Tensor 27 spectrometer. Elemental analyses were performed by Mrs Anne Davies and Mr Martin Jennings at The University of Manchester School of Chemistry Microanalysis Service, Manchester, UK. Elemental analysis results for 1-Ln and 2-Ln consistently gave low carbon values, which we assign to carbide formation as other analytical techniques were indicative of bulk purity. General synthetic procedures for 1-Ln, 2-Ln and 3-Ce are given below; full details are in the ESI. $\dagger$

\section{General procedure for synthesis of 1-Ln}

Di- $n$-butyl ether $(20 \mathrm{~mL})$ was added to a pre-cooled $\left(-78{ }^{\circ} \mathrm{C}\right)$ Rotaflow tap-appended ampoule containing $\left[\mathrm{Ln}\left(\mathrm{BH}_{4}\right)_{3}(\mathrm{THF})_{3.5}\right]$ (2 mmol) and $\mathrm{K}(\mathrm{Htp})(4 \mathrm{mmol})$. The reaction mixture was refluxed for 16 hours, allowed to settle and filtered. The solution was concentrated to ca. $2 \mathrm{~mL}$ and stored at $-25{ }^{\circ} \mathrm{C}$ overnight to afford 1-Ln ( $\mathrm{Ln}=\mathrm{La}, \mathrm{Ce}, \mathrm{Nd}, \mathrm{Sm})$.

1-La. Colourless crystals $(0.341 \mathrm{~g}, 31 \%)$. Anal calcd (\%) for $\mathrm{C}_{48} \mathrm{H}_{88} \mathrm{~B}_{2} \mathrm{La}_{2} \mathrm{P}_{4}$ : C, 52.92; H, 8.15. Found (\%): C, 51.12; H, 8.17. ${ }^{1} \mathrm{H}$ NMR $\left(\mathrm{C}_{6} \mathrm{D}_{6}, 400 \mathrm{MHz}, 298 \mathrm{~K}\right): \delta=1.52\left(72 \mathrm{H}, \mathrm{C}\left(\mathrm{CH}_{3}\right)_{3}\right), 7.35$ $(8 \mathrm{H}, \mathrm{Htp}-\mathrm{CH}), \mathrm{BH}_{4}$ signals could not be observed. ${ }^{11} \mathrm{~B}\left\{{ }^{1} \mathrm{H}\right\}$ NMR $\left(\mathrm{C}_{6} \mathrm{D}_{6}, 128 \mathrm{MHz}, 298 \mathrm{~K}\right): \delta=-20.89\left(B \mathrm{H}_{4}\right) .{ }^{11} \mathrm{~B} \mathrm{NMR}$ $\left(\mathrm{C}_{6} \mathrm{D}_{6}, 128 \mathrm{MHz}, 298 \mathrm{~K}\right): \delta=-20.91\left(\mathrm{br} \mathrm{q},{ }^{1} J_{\mathrm{BH}}=84.1 \mathrm{~Hz}, B \mathrm{H}_{4}\right)$. ${ }^{13} \mathrm{C}\left\{{ }^{1} \mathrm{H}\right\} \operatorname{NMR}\left(\mathrm{C}_{6} \mathrm{D}_{6}, 100 \mathrm{MHz}, 298 \mathrm{~K}\right): \delta=34.50\left(\mathrm{~d},{ }^{3} J_{\mathrm{PC}}=6.9\right.$ $\left.\mathrm{Hz}, \mathrm{C}\left(\mathrm{CH}_{3}\right)_{3}\right), 37.02\left(\mathrm{~d},{ }^{2} J_{\mathrm{PC}}=15.7 \mathrm{~Hz}, C\left(\mathrm{CH}_{3}\right)_{3}\right), 125.01$ (s, Htp$\mathrm{CH}), 178.08\left(\mathrm{~d},{ }^{1} J_{\mathrm{PC}}=59.7 \mathrm{~Hz}, \mathrm{PC}\right) .{ }^{31} \mathrm{P}\left\{{ }^{1} \mathrm{H}\right\} \mathrm{NMR}\left(\mathrm{C}_{6} \mathrm{D}_{6}\right.$, $162 \mathrm{MHz}, 298 \mathrm{~K}$ ): $\delta=105.65$ (Htp-P). FTIR (ATR, microcrystalline): $\tilde{\nu}=2957$ (s), 2900 (m), 2864 (m), 2375 (br, w, B-H str.), 2274 (br, m, B-H str.), 2208 (br, w, B-H str.), 1473 (s), 1460 (s), 1416 (w), 1391 (s), 1359 (s), 1301 (w), 1247 (s), 1194 (s), 1151 (br, m), 1115 (br, s), 1065 (s), 1037 (s), 1020 (w), 991 (s), 920 (w), $888(\mathrm{w}), 817$ (s), $794(\mathrm{~s}), 720$ (s), 660 (s), 611 (s), 590 (s), 517 (w), $429(\mathrm{w}) \mathrm{cm}^{-1}$.

1-Ce. Orange crystals (0.442 g, 41\%). Anal calcd (\%) for $\mathrm{C}_{48} \mathrm{H}_{88} \mathrm{~B}_{2} \mathrm{Ce}_{2} \mathrm{P}_{4}$ : C, 52.80; H, 8.13. Found (\%): C, 51.80; H, 8.11. $\mu_{\text {eff }}$ (Evans method, $\left.298 \mathrm{~K}, \mathrm{C}_{6} \mathrm{D}_{6}\right): 3.43 \mu_{\mathrm{B}} \cdot{ }^{1} \mathrm{H}$ NMR $\left(\mathrm{C}_{6} \mathrm{D}_{6}\right.$, $400 \mathrm{MHz}, 298 \mathrm{~K}): \delta=-35.05\left(\mathrm{br}, 8 \mathrm{H}, \nu \frac{1}{2} \sim 1400 \mathrm{~Hz}, \mathrm{~B} H_{4}\right),-4.63$ (br, $4 \mathrm{H}, \nu \frac{1}{2}=60 \mathrm{~Hz}$, Htp-CH), $-3.70\left(\mathrm{br}, 72 \mathrm{H}, \nu \frac{1}{2}=20 \mathrm{~Hz}\right.$, $\left.\mathrm{C}\left(\mathrm{CH}_{3}\right)_{3}\right),-2.64$ (br, $\left.4 \mathrm{H}, \nu \frac{1}{2}=60 \mathrm{~Hz}, \mathrm{Htp}-\mathrm{CH}\right) .{ }^{11} \mathrm{~B}\left\{{ }^{1} \mathrm{H}\right\}$ NMR $\left(\mathrm{C}_{6} \mathrm{D}_{6}, 128 \mathrm{MHz}, 298 \mathrm{~K}\right): \delta=-3.90\left(\mathrm{BH}_{4}\right)$. The paramagnetism of 1-Ce precluded assignment of its ${ }^{13} \mathrm{C}\left\{{ }^{1} \mathrm{H}\right\}$ and ${ }^{31} \mathrm{P}\left\{{ }^{1} \mathrm{H}\right\}$ NMR spectra. FTIR (ATR, microcrystalline): $\tilde{\nu}=2948$ (br, m), 2872 (br, m), 1644 (m), 1513 (s), 1459 (s), 1383 (br, m), 1276 (m), 1246 (w), 1084 (s), 977 (s), 878 (br, s), 866 (br, s) 820 (w), 796 (w), $774(\mathrm{~s}), 740(\mathrm{~s}), 705(\mathrm{~s}), 683(\mathrm{~s}), 661(\mathrm{~s}), 636(\mathrm{~s}), 611(\mathrm{~m})$, $554(\mathrm{w}), 521(\mathrm{w}), 422(\mathrm{w}) \mathrm{cm}^{-1}$.

1-Nd. Green crystals $(0.160 \mathrm{~g}, 15 \%)$. Anal calcd (\%) for $\mathrm{C}_{48} \mathrm{H}_{88} \mathrm{~B}_{2} \mathrm{Nd}_{2} \mathrm{P}_{4}$ : C, 52.41; H, 8.07. Found (\%): C, 50.41; H, 8.07. $\mu_{\text {eff }}$ (Evans method, $\left.298 \mathrm{~K}, \mathrm{C}_{6} \mathrm{D}_{6}\right): 4.02 \mu_{\mathrm{B}} \cdot{ }^{1} \mathrm{H}$ NMR $\left(\mathrm{C}_{6} \mathrm{D}_{6}\right.$, $500 \mathrm{MHz}, 298 \mathrm{~K}): \delta=-13.86$ (br, 8H, $\nu \frac{1}{2}=130 \mathrm{~Hz}, \mathrm{Htp}-\mathrm{CH}$ ), $-5.09\left(\mathrm{br}, 72 \mathrm{H}, \nu \frac{1}{2}=150 \mathrm{~Hz}, \mathrm{C}\left(\mathrm{CH}_{3}\right)_{3}\right), \mathrm{BH}_{4}$ signals could not be observed. The paramagnetism of 1-Nd precluded assignment of its ${ }^{13} \mathrm{C}\left\{{ }^{1} \mathrm{H}\right\},{ }^{11} \mathrm{~B}\left\{{ }^{1} \mathrm{H}\right\}$ and ${ }^{31} \mathrm{P}\left\{{ }^{1} \mathrm{H}\right\}$ NMR spectra. FTIR (ATR, microcrystalline): $\tilde{\nu}=2956$ (br, m), 2870 (br, m), $1644(\mathrm{~m})$, 1513 (s), 1459 (s), 1365 (br, m), 1276 (br, m), 1247 (br, m), 1085 (s), 977 (s), 921 (w), 894 (br, s) 877 (br, s), 865 (br, s), 821 (w), $797(\mathrm{~m}), 774(\mathrm{~m}), 755(\mathrm{~m}), 705(\mathrm{~s}), 683(\mathrm{~s}), 661(\mathrm{~s}), 635(\mathrm{~s})$, 
$611(\mathrm{~s}), 592(\mathrm{~m}), 552(\mathrm{~m}), 542(\mathrm{w}), 498(\mathrm{w}), 475(\mathrm{~m}), 413(\mathrm{~s})$ $\mathrm{cm}^{-1}$.

1-Sm. Orange crystals (0.077 g, 7\%). Anal calcd (\%) for $\mathrm{C}_{48} \mathrm{H}_{88} \mathrm{~B}_{2} \mathrm{Sm}_{2} \mathrm{P}_{4}: \mathrm{C}, 51.83 ; \mathrm{H}$, 7.98. Found (\%): C, 51.17; H, 8.03. $\mu_{\text {eff }}$ (Evans method, $\left.298 \mathrm{~K}, \mathrm{C}_{6} \mathrm{D}_{6}\right): 2.38 \mu_{\mathrm{B}} \cdot{ }^{1} \mathrm{H}$ NMR $\left(\mathrm{C}_{6} \mathrm{D}_{6}\right.$, $400 \mathrm{MHz}, 298 \mathrm{~K}): \delta=-25.22\left(\mathrm{br}, 8 \mathrm{H}, \nu \frac{1}{2} \sim 800 \mathrm{~Hz}, \mathrm{~B} H_{4}\right),-0.54$ $\left(72 \mathrm{H}, \nu \frac{1}{2}=12 \mathrm{~Hz}, \mathrm{C}\left(\mathrm{CH}_{3}\right)_{3}\right), 16.40$ (br, 8H, $\left.\nu \frac{1}{2}=90 \mathrm{~Hz}, \mathrm{Htp}-\mathrm{CH}\right)$. ${ }^{11} \mathrm{~B}\left\{{ }^{1} \mathrm{H}\right\}$ NMR $\left(\mathrm{C}_{6} \mathrm{D}_{6}, 128 \mathrm{MHz}, 298 \mathrm{~K}\right): \delta=-71.18\left(B \mathrm{H}_{4}\right)$. The paramagnetism of 1-Sm precluded assignment of its ${ }^{13} \mathrm{C}\left\{{ }^{1} \mathrm{H}\right\}$ and ${ }^{31} \mathrm{P}\left\{{ }^{1} \mathrm{H}\right\}$ NMR spectra. FTIR (ATR, microcrystalline): $\tilde{\nu}=$ 2957 (s), 2900 (m), 2865 (m), 2447 (br, m, B-H str.), 2376 (br, w, B-H str.), 2225 (br, s, B-H str.), 1460 (s), 1416 (s), 1391 (s), 1359 (s), 1301 (m), 1248 (s), 1194 (s), 1167 (w), 1085 (br, s), 1065 (s), 1020 (w), 991 (s), 920 (s), 893 (w), 824(w), 799 (s), 759 (s), $721(\mathrm{~m}), 694(\mathrm{~s}), 661(\mathrm{~s}), 611(\mathrm{~s}), 591(\mathrm{~s}), 517(\mathrm{w}), 464(\mathrm{w})$, $435(\mathrm{w}) \mathrm{cm}^{-1}$.

\section{General procedure for synthesis of $2-\mathrm{Ln}$}

Dimethoxyethane $(20 \mathrm{~mL})$ was added to a pre-cooled $\left(-78^{\circ} \mathrm{C}\right)$ Rotaflow tap-appended ampoule containing $\left[\mathrm{Ln}\left(\mathrm{BH}_{4}\right)_{3}(\mathrm{THF})_{3.5}\right]$ $(1.5 \mathrm{mmol})$ and $\mathrm{K}(\mathrm{Htp})(3.0 \mathrm{mmol})$. The reaction mixture was allowed to warm to room temperature and refluxed for 16 hours, allowed to settle and filtered. Volatiles were removed in vacuo and toluene $(20 \mathrm{~mL})$ was added. The resultant suspension was allowed to settle and filtered. The filtrate was concentrated to $3 \mathrm{~mL}$ and stored at $-25^{\circ} \mathrm{C}$ to afford 2-Ln.

2-La. Colourless crystals (0.185 g, 16\%). Anal calcd (\%) for $\mathrm{C}_{64} \mathrm{H}_{136} \mathrm{~B}_{4} \mathrm{La}_{2} \mathrm{~K}_{2} \mathrm{O}_{8} \mathrm{P}_{4}: \mathrm{C}, 49.37 ; \mathrm{H}, 8.81$. Found (\%): C, 48.44; $\mathrm{H}$, 8.84. ${ }^{1} \mathrm{H}$ NMR $\left(\mathrm{C}_{6} \mathrm{D}_{6}, 400 \mathrm{MHz}, 298 \mathrm{~K}\right): \delta=1.50$ and $1.75(\mathrm{br}$, $\left.72 \mathrm{H}, \mathrm{C}\left(\mathrm{CH}_{3}\right)_{3}\right), 3.08\left(\mathrm{~s}, 24 \mathrm{H}, \mathrm{OCH}_{3}\right), 3.12\left(\mathrm{~s}, 16 \mathrm{H}, \mathrm{OCH}_{2}\right)$, 7.20-7.40 (br, 4H, Htp-CH), $\mathrm{BH}_{4}$ signals could not be observed. ${ }^{11} \mathrm{~B}\left\{{ }^{1} \mathrm{H}\right\} \operatorname{NMR}\left(\mathrm{C}_{6} \mathrm{D}_{6}, 128 \mathrm{MHz}, 298 \mathrm{~K}\right): \delta=-22.70\left(B \mathrm{H}_{4}\right),-20.98$ $\left(B \mathrm{H}_{4}\right) .{ }^{13} \mathrm{C}\left\{{ }^{1} \mathrm{H}\right\}$ NMR $\left(\mathrm{C}_{6} \mathrm{D}_{6}, 100 \mathrm{MHz}, 298 \mathrm{~K}\right): \delta=34.55\left(\mathrm{~d},{ }^{3} J_{\mathrm{PC}}\right.$ $\left.=6.9 \mathrm{~Hz}, \mathrm{C}\left(\mathrm{CH}_{3}\right)_{3}\right), 37.00\left(\mathrm{~d},{ }^{2} J_{\mathrm{PC}}=15.7 \mathrm{~Hz}, C\left(\mathrm{CH}_{3}\right)_{3}\right)$, Htp- $C$ signals could not be observed. ${ }^{31} \mathrm{P}\left\{{ }^{1} \mathrm{H}\right\}$ NMR $\left(\mathrm{C}_{6} \mathrm{D}_{6}, 162 \mathrm{MHz}\right.$, $298 \mathrm{~K}): \delta=96.49$ (Htp-P). FTIR (ATR, microcrystalline): $\tilde{\nu}=2946$ (s), 2899 (m), 2868 (w), 2427 (s, B-H str.), 2224 (br, m, B-H str.), 2178 (br, m, B-H str.), 1458 (s), 1390 (s), 1363 (s), 1355 (s), 1235 (s), 1152 (s), 1075 (s), 1022 (s), 990 (m), 842 (s), 797 (s), 776 (s), 723 (s), 660 (s), 617 (s), 593 (s) cm $\mathrm{cm}^{-1}$.

2-Ce. Yellow crystals $(0.539 \mathrm{~g}, 46 \%)$. Anal calcd (\%) for $\mathrm{C}_{64} \mathrm{H}_{136} \mathrm{~B}_{4} \mathrm{Ce}_{2} \mathrm{~K}_{2} \mathrm{O}_{8} \mathrm{P}_{4}: \mathrm{C}, 49.30 ; \mathrm{H}, 8.79$. Found (\%): C, 47.86; $\mathrm{H}$, 8.61. $\mu_{\text {eff }}$ (Evans method, $\left.298 \mathrm{~K}, \mathrm{C}_{6} \mathrm{D}_{6}\right): 3.52 \mu_{\mathrm{B}} \cdot{ }^{1} \mathrm{H}$ NMR $\left(\mathrm{C}_{6} \mathrm{D}_{6}\right.$, $400 \mathrm{MHz}, 298 \mathrm{~K}): \delta=-3.68\left(\mathrm{br}, 48 \mathrm{H}, \nu \frac{1}{2}=90 \mathrm{~Hz}, \mathrm{C}\left(\mathrm{CH}_{3}\right)_{3}\right)$, -1.84 (br, $\left.24 \mathrm{H}, \nu \frac{1}{2}=140 \mathrm{~Hz}, \mathrm{C}\left(\mathrm{CH}_{3}\right)_{3}\right), 3.54$ (br, $40 \mathrm{H}, \nu \frac{1}{2}=25$ $\mathrm{Hz}, \mathrm{CH}_{2} \mathrm{OCH}_{3}$ ), 11.35 (br, $\left.8 \mathrm{H}, \nu \frac{1}{2}=220 \mathrm{~Hz}, \mathrm{Htp}-\mathrm{CH}\right), \mathrm{BH}_{4}$ signals could not be observed. ${ }^{11} \mathrm{~B}\left\{{ }^{1} \mathrm{H}\right\}$ NMR $\left(\mathrm{C}_{6} \mathrm{D}_{6}, 128 \mathrm{MHz}\right.$, $298 \mathrm{~K}): \delta=13.35\left(\mathrm{BH}_{4}\right)$. The paramagnetism of 2-Ce precluded assignment of its ${ }^{13} \mathrm{C}\left\{{ }^{1} \mathrm{H}\right\}$ and ${ }^{31} \mathrm{P}\left\{{ }^{1} \mathrm{H}\right\}$ NMR spectra. FTIR (ATR, microcrystalline): $\tilde{\nu}=2945$ (s), 2899 (m), 2866 (w), 2828 (w), 2427 (s, B-H str.), 2225 (s, B-H str.), 1457 (s), 1355 (s), 1234 (s), 1194 (s), 1153 (s), 1098 (s), 1076 (s), 1019 (s), 854 (s), 776 (s), 724 (s), 660 (s), 617 (s), 593 (s) cm $\mathrm{cm}^{-1}$.

3-Ce. Diethyl ether $(20 \mathrm{~mL})$ was added to a Schlenk containing a pre-cooled $\left(-78{ }^{\circ} \mathrm{C}\right)$ mixture of $\left[\mathrm{Ce}\left(\mathrm{BH}_{4}\right)_{3}(\mathrm{THF})_{3.5}\right]$ $(0.874 \mathrm{~g}, 2 \mathrm{mmol})$ and $\mathrm{K}(\mathrm{Htp})(0.937 \mathrm{~g}, 4 \mathrm{mmol})$. The reaction mixture was allowed to warm to room temperature and stirred for 16 hours, settled and filtered. The resultant yellow solution was concentrated to $3 \mathrm{~mL}$ and stored at $-25{ }^{\circ} \mathrm{C}$ to afford 3-Ce as orange crystals $(0.456 \mathrm{~g}, 31 \%)$. Anal calcd (\%) for $\mathrm{C}_{24} \mathrm{H}_{48} \mathrm{~B}_{2} \mathrm{CeKP}_{2}$ (desolvated): C, 48.09; H, 8.07. Found (\%): C, 48.03; H, 8.08. $\mu_{\text {eff }}$ (Evans method, $298 \mathrm{~K}, \mathrm{C}_{6} \mathrm{D}_{6}$ ): $2.33 \mu_{\mathrm{B}} \cdot{ }^{1} \mathrm{H}$ NMR $\left(\mathrm{C}_{6} \mathrm{D}_{6}, 500 \mathrm{MHz}, 298 \mathrm{~K}\right): \delta=-3.45\left(\mathrm{br}, 36 \mathrm{H}, \nu \frac{1}{2}=250 \mathrm{~Hz}\right.$, $\left.\mathrm{C}\left(\mathrm{CH}_{3}\right)_{3}\right), 1.44\left(\mathrm{br}, 4 \mathrm{H}, \nu \frac{1}{2}=120 \mathrm{~Hz}, \mathrm{Htp}-\mathrm{CH}\right), \mathrm{B} H_{4}$ signals could not be observed. The paramagnetism of 3-Ce precluded assignment of its ${ }^{13} \mathrm{C}\left\{{ }^{1} \mathrm{H}\right\},{ }^{11} \mathrm{~B}\left\{{ }^{1} \mathrm{H}\right\}$ and ${ }^{31} \mathrm{P}\left\{{ }^{1} \mathrm{H}\right\}$ NMR spectra. FTIR (ATR, microcrystalline): $\tilde{\nu}=2957$ (s), 2901 (m), 2866 (m), 2429 (br, w, B-H str.), 2373 (br, w, B-H str.), 2277 (s, B-H str.), 2214 (s, B-H str.), 1460 (s), 1391 (s), 1359 (s), 1248 (s), 1194 (s), 1163 (s), 1115 (s), 1038 (s), $1020(\mathrm{~m}), 865$ (br, m), 808 (s), 721 (s), 660 (s), 612 (s), 591 (s), $549(\mathrm{w}) \mathrm{cm}^{-1}$.

\section{Conflicts of interest}

There are no conflicts to declare.

\section{Acknowledgements}

We thank the China Scholarship Council (studentship for J. L.) the Engineering and Physical Sciences Research Council (EPSRC; EP/P002560/1 for F. O., studentship for L. E. N.), the European Research Council (ERC; Consolidator Grant for D. P. M. and postdoctoral funding for P. J. C. and M. J. G.), The University of Manchester Computational Shared Facility and the EPSRC UK National Electron Paramagnetic Resonance Service for generously supporting this work. We thank Carlo Bawn and Dr Ralph Adams from the NMR Spectroscopy Service for assistance with VT studies. Research data supporting this publication are available from Mendeley Data at DOI: 10.17632/656d55pc7p.1.

\section{Notes and references}

1 Lanthanides: Resource Sustainability, in The Rare Earth Elements: Fundamentals and Applications, ed. D. A. Atwood, Wiley, United Kingdom, 2012.

2 G. Wilkinson and J. M. Birmingham, J. Am. Chem. Soc., 1954, 76, 6210.

3 (a) H. Schumann, J. A. Meese-Marktscheffel and L. Esser, Chem. Rev., 1995, 95, 865; (b) O. Walter, Chem. - Eur. J., 2019, 25, 2927; (c) M. Ephritikhine, Organometallics, 2013, 32, 2464.

4 W. J. Evans, Organometallics, 2016, 35, 3088.

5 (a) P. Le Floch, Coord. Chem. Rev., 2006, 250, 627; (b) F. Nief, Dalton Trans., 2010, 39, 6589.

6 (a) S. Labouille, F. Nief, X.-F. Le Goff, L. Maron, D. R. Kindra, H. L. Houghton, J. W. Ziller and W. J. Evans, Organometallics, 2012, 31, 5196; (b) H. M. Nicholas and D. P. Mills, in Encyclopedia of Inorganic and Bioinorganic Chemistry, ed. R. A. Scott, John Wiley, Chichester, 2017. 
7 F. Nief and F. Mathey, J. Chem. Soc., Chem. Commun., 1989, 800.

8 S. M. Cendrowski-Guillaume, G. L. Gland, M. Nierlich and M. Ephritikhine, Organometallics, 2000, 19, 5654.

9 F. Jaroschik, F. Nief, X.-F. Le Goff and L. Ricard, Organometallics, 2007, 26, 3552.

10 F. Jaroschik, F. Nief and X.-F. L. Goff, Polyhedron, 2009, 28, 2744 .

11 H.-J. Gosink, F. Nief, L. Ricard and F. Mathey, Inorg. Chem., 1995, 34, 1306.

12 F. Jaroschik, A. Momin, A. Martinez, D. Harakat, L. Ricard, X.-F. Le Goff and G. Nocton, Organometallics, 2016, 35, 2032.

13 D. H. Woen, C. M. Kotyk, T. J. Mueller, J. W. Ziller and W. J. Evans, Organometallics, 2017, 36, 4558.

14 P. Evans, D. Reta, G. F. S. Whitehead, N. F. Chilton and D. P. Mills, J. Am. Chem. Soc., 2019, 141, 19935.

15 (a) N. A. Pushkarevsky, I. Y. Ilyin, P. A. Petrov, D. G. Samsonenko, M. R. Ryzhikov, P. W. Roesky and S. N. Konchenko, Organometallics, 2017, 36, 1287; (b) C. D. Sofield and R. A. Andersen, J. Organomet. Chem., 1995, 501, 271.

16 (a) T. J. Marks and J. R. Kolb, Chem. Rev., 1977, 77, 263; (b) F. Ortu, D. Packer, J. Liu, M. Burton, A. Formanuik and D. P. Mills, J. Organomet. Chem., 2018, 857, 45.

17 F. Nief, B. T. de Borms, L. Ricard and D. Carmichael, Eur. J. Inorg. Chem., 2005, 637.

18 A. Schnepf, G. Stößer, D. Carmichael, F. Mathey and H. Schnöckel, Angew. Chem., Int. Ed., 1999, 38, 1646.
19 (a) E. B. Lobkovsky, Y. K. Gun'ko, B. M. Bulychev, V. K. Belsky, G. L. Soloveichik and M. Y. Antipin, J. Organomet. Chem., 1991, 406, 343; (b) Y. K. Gun'ko, B. M. Bulychev, G. L. Soloveichik and V. K. Belsky, J. Organomet. Chem., 1992, 424, 289.

20 V. A. Volkovich, A. B. Ivanov, S. M. Yakimov, D. V. Tsarevskii, O. A. Golovanova, V. V. Sukhikh and T. R. Griffiths, AIP Conf. Proc., 2016, 1767, 020023-1.

21 S. K. Sur, J. Magn. Reson., 1989, 82, 169.

22 O. Kahn, Molecular Magnetism, VCH, Weinheim, 1993.

23 F. Aquilante, J. Autschbach, R. K. Carlson, L. F. Chibotaru, M. G. Delcey, L. De Vico, I. F. Galván, N. Ferré, L. M. Frutos, L. Gagliardi, M. Garavelli, A. Giussani, C. E. Hoyer, G. Li Manni, H. Lischka, D. Ma, P. Å. Malmqvist, T. Müller, A. Nenov, M. Olivucci, T. B. Pedersen, D. Peng, F. Plasser, B. Pritchard, M. Reiher, I. Rivalta, I. Schapiro, J. Segarra-Martí, M. Stenrup, D. G. Truhlar, L. Ungur, A. Valentini, S. Vancoillie, V. Veryazov, V. P. Vysotskiy, O. Weingart, F. Zapata and R. Lindh, J. Comput. Chem., 2016, 37, 506.

24 (a) C. A. P. Goodwin, F. Ortu, D. Reta, N. F. Chilton and D. P. Mills, Nature, 2017, 548, 439; (b) K. R. McClain, C. A. Gould, K. Chakarawet, S. J. Teat, T. J. Groshens, J. R. Long and B. G. Harvey, Chem. Sci., 2018, 9, 8492; (c) F.-S. Guo, B. M. Day, Y.-C. Chen, M.-L. Tong, A. Mansikkamäki and R. A. Layfield, Science, 2018, 362, 1400. 25 E. B. Lobkovsky, Y. K. Gun'ko, B. M. Bulychev, V. K. Belsky, G. L. Soloveichik and M. Y. Antipin, J. Organomet. Chem., 1991, 406, 343-352. 